\title{
SCIENTIFIC REP RTS OPEN Author Correction: Diversity in gut bacterial community of school-age children in Asia
}

\author{
Jiro Nakayama ${ }^{1}$, Koichi Watanabe ${ }^{2}$, Jiahui Jiang ${ }^{1}$, Kazunori Matsuda ${ }^{2,3}$, Shiou-Huei Chao ${ }^{4}$, \\ Pri Haryono ${ }^{5}$, Orawan La-ongkham ${ }^{6}$, Martinus-Agus Sarwoko ${ }^{5}$, I. Nengah Sujaya ${ }^{7}$, \\ Liang Zhao ${ }^{8}$, Kang-Ting Chen ${ }^{9}$, Yen-Po Chen ${ }^{10}$, Hsueh-Hui Chiu ${ }^{11}$, Tomoko Hidaka', \\ Ning-Xin Huang ${ }^{9}$, Chikako Kiyohara ${ }^{12}$, Takashi Kurakawa ${ }^{2}$, Naoshige Sakamoto ${ }^{1}$, \\ Kenji Sonomoto ${ }^{1}$, Kousuke Tashiro ${ }^{1}$, Hirokazu Tsuji ${ }^{2}$, Ming-Ju Chen ${ }^{10}$, Vichai Leelavatcharamas ${ }^{13}$, \\ Chii-Cherng Liao ${ }^{11}$, Sunee Nitisinprasert ${ }^{6}$, Endang S. Rahayu ${ }^{5}$, Fa-Zheng Ren ${ }^{8}$, \\ Ying-Chieh Tsai ${ }^{4}$ \& Yuan-Kun Lee ${ }^{9}$
}

Correction to: Scientific Reports https://doi.org/10.1038/srep08397, published online 23 February 2015

The Supplementary Information published with this Article contains errors. In Supplementary Tables S4 and S5, the data in the Yogjakarta columns are duplicates of the data in the Bali columns.

The correct Supplementary Information file is provided below.

Supplementary information accompanies this paper at https://doi.org/10.1038/s41598-019-42780-z.

(c) (i) Open Access This article is licensed under a Creative Commons Attribution 4.0 International License, which permits use, sharing, adaptation, distribution and reproduction in any medium or format, as long as you give appropriate credit to the original author(s) and the source, provide a link to the Creative Commons license, and indicate if changes were made. The images or other third party material in this article are included in the article's Creative Commons license, unless indicated otherwise in a credit line to the material. If material is not included in the article's Creative Commons license and your intended use is not permitted by statutory regulation or exceeds the permitted use, you will need to obtain permission directly from the copyright holder. To view a copy of this license, visit http://creativecommons.org/licenses/by/4.0/.

(C) The Author(s) 2019 